\title{
Have Multibank Holding Companies Affected Commercial Bank Performance?
}

\author{
NORMAN N. BOWSHER
}

(n)

INCE the late 1960 s there has been a rapid expansion of multibank holding companies which has had far reaching impacts on the structure of banking in the nation. These multibank holding companies (MBHCs) were established as alternatives to branching systems in a number of states where branch banking was prohibited or severely limited." The holding company device for controlling and managing banks is not new - having been used since about the turn of the century - but its importance has increased dramatically in the last decade. MBHCs' control of commercial bank deposits increased from 8 percent at the end of 1965 , to 16 percent at the end of 1970 , and to 34 percent at yearend 1976 .

The rapid expansion of MBHCs in recent years and the changes in banking structures and practices brought about by this development have generated much controversy regarding the merits and desirability of holding companies. This article reviews evidence on some major issues raised by the emergence of MBHCs.

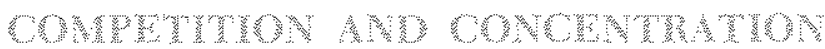

There has been a longstanding public concern in this country over the possibilities for excessive concentration in banking. Many have feared that increased concentration would place resource allocation in the hands of a relatively small number of banking organizations in the financial centers. Rellecting these attitudes and policies based on them, the structure of American banking has been unique in the world, with its numerous independent banking institutions. At the same time, because of limits on bank entry and branching maximum interest rates on deposits, and other regulations, competition has been limited and individual banks, particularly in some smaller communities, have attained some degree of monopoly power.

\footnotetext{
1MBHCs have been established in various branch banking states. Organization as an MBHC can have advantages over that of a branch banking system. For instance, a holding conpany system can of ten maintain lower aggregate reserves than the same-sized branch network.
}

A chief issue which has emerged with MBHC development has been the effects that these holding companies have had on concentration and competition in banking. With entry into banking limited by prevailing government regulations, acquisitions by holding companies could increase concentration by reducing or eliminating competition, and permit the remaining firms in the market to obtain monopolistic profits by raising prices and lowering services. Since there are no widely agreed upon measures of concentration and competition, and since in some ways increased concentration could be conststent with more, not less, competition, evaluations have not been uniform. ${ }^{2}$

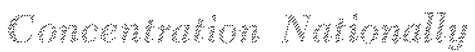

From a review of banking developments since the mid-1960s, it does not appear that national concentration has been a crucial problem. Although numerous acquisitions did affect concentration from what it would likely have been otherwise, given all other factors, concentration has changed only slightly during the period of rapid holding company expansion.

Concentration, as measured by total domestic deposits held by the 100 largest banking organizations in the country, changed little in the period 1957 to 1968 when holding company activity was relatively dormant. From a level of 48.2 percent in 1957 , concentration rose slightly to 49 percent in 1968. However, despite an acceleration in holding company acquisitions after 1968, many of which were made by the 100 largest banking organizations, nationwide

\footnotetext{
2Evidence has been advanced which supports both the hypothesis that increased market concentration results from efficiency of large organizations and the hypothesis that increased concentration facilitates collusion among firms. The relationship between efficiency and concentration, by itself, implies that customers gain as a result of higher concentration, but the relationship between collusion and concentration, by itself, inplies that customers lose as a result of higher concentration. Since fewer restrtictions on holding companies are associated with higher concentration, there are both potential benefits and costs for bank customers from such lessened restrictions. Gerald P. Dwyer, Ir. and William C. Niblack, "Branching, Holding Companies, and Banking Concentration in the Eighth District," this Reviev (July 1974), pp. 11-18.
} 
concentration by these firms decreased from 49 percent of domestic deposits to 47 percent in $1973 .{ }^{3}$

More recent calculations find that between 1968 and mid-1977 the 10 largest banking organizations' share of domestic deposits declined from 20.4 to 18.3 percent while the share of the top 25 dropped from 31.9 to 28 percent. The 100 largest organizations' share declined from 49.7 to 45 percent over this period. ${ }^{4}$

The apparent reason for this somewhat surprising result is that growth of domestic deposits (as distinct from foreign) was slower at the larger banking offices during the 1968-77 period than deposit growth at smaller banking offices. Also, there was a constraining influence on the larger organizations from antitrust laws and policies. Although over one-half of the 100 largest bank holding companies acquired other banks through the holding company device, a large portion of those acquired were de novo or small "foothold" acquisitions.

Nevertheless, acquisitions by the 100 largest banking organizations between 1968 and 1973 did maintain nationwide concentration of domestic deposits above what otherwise would have prevailed. If the quantitative impact of these acquisitions is subtracted from the 1973 actual ratio of concentration, the resultant adjusted nationwide concentration ratio for 1973 would have been 44.7 percent. Since the actual ratio was 47 percent, holding company acquisitions in the 1968-73 period, everything else equal, increased concentration by 2.3 percentage points above the level that would have existed in the absence of such accuisitions. Thus, the pronounced increase in the share of total deposits of banks in MBHCs, mentioned in the introduction, reflected primarily the largest banks in the nation forming MBHCs and not acquisitions by the large banking organizations.

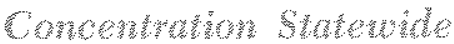

There is justification for measuring concentration in an area smaller than the nation since the market for most banks is considerably less than the entire country. Since the state is the largest area within which banks can legally branch and form holding companies,

¿Samuel H. Talley, "The Impact of Holding Company Acquisitions on Aggregate Concentration in Banking" Staff Economic Studies (80), Board of Governors of the Federal Reserve System, 1974

${ }^{4}$ Statement by Philip E. Coldwell, member of the board of Governors of the Federal Reserve System, before the Committee on Banking, Housing and Urban Affairs, United States Senate, March 7, 1978 . and hence attempt to gain monopoly power, some feel that states are the relevant areas for measuring concentration. ${ }^{5}$ Also, interbank rivalry may be dependent not only on local market concentration, but also on the degree to which a few large banking organizations in a state, each of which has banking offices in several common local markets, agree not to engage in competitive behavior in any such local markets. ${ }^{\theta}$

Available evidence indicates that trends in statewide concentration in banking have varied markedly from state to state, with average changes remaining small. Between 1960 and 1976, there was no overall trend toward increased concentration of the three largest banking organizations in each state. Calculations of averages of changes indicate that states which allowed statewide branching experienced a very small increase in the proportion of domestic deposits held by the three largest banking organizations: 0.2 percentage point. Limited branching states and unit banking states experienced average decreases of 1.7 and 2.9 percentage points, respectively. Among statewide branching states, those with the highest concen tration in 1960 exhibited the greatest decline in concentration, while those with the lowest concentration exhibited the greatest increase. ${ }^{7}$

Among the five largest banking institutions in each state, an increase in concentration occurred in 28 states, a decline in 22 states, with one unchanged in the 1968.73 period (the District of Columbia was treated as a state). The median increase for all states

IIt might be noted, however, that the Justice Department has failed to win a banking case on the grounds of statewide concentration alone or the closely related grounds of potential competition statewide. See Aubrey B. Willacy and Hazel M. Willacy, "Conglomerate Bark Mergers and Clayton 7: Is Potential Competition the Answer?" Banking Law Joumal (February 1976), pp. 148-195. Nevertheless, the legal issue of whether states are appropriate areas for administering antitrust policies is not settled since legislatures in a few states prohibit expansion by merger or acquisition beyond some statewide concentration level. See Katharine Gibson and Steven J. Weiss, "State-Imposed Limitations on Multibank Holding Company Growth," Proceedings of a Conference on Bank Stricture and Competition, Federal Reserve Bank of Chicago, 1976, pp. 208-209, Also, Senate Bill S 72, the "Competition inz Banking Act of 1977," would prohibit bank mergers or hold ing company acquisitions if the resulting banking institution would control more than 20 percent of the banking assets within the state

"See Elinor Harris Solomon, "Bank Merger Policy and Prob" lerns: A Linkage Theory of Oligopoly, Journal of Money, Credit and Banking (August 1970), pp. 323m336.

${ }^{7}$ Statement by Philip E. Coldwell, member of Board of Govemors of the Federal Reserve System, before the Committee on Banking, Housing and Urban Affairs, United States Senate, March 7, 1978. See also Manferd O. Peterson, "Aggregate Bark Concentration and the Competition in Barking Act of 1975," Issues in Bank Regulation (Park Ridge, nllinois: Bank Administration Institute, 1977), pp. 37-41. 
was only 0.7 percentage point. In the 38 states permitting MBHCs, concentration tended to increase during the period, while in the 13 states which prohibited them, concentration tended to decline. Nevertheless, the impact of MBHC acquisitions on statewide concentration was limited almost entirely to states with low or moderate concentration. ${ }^{8}$

It might have been expected that holding company activity would have its greatest impact on concentration at the state level, since holding companies are prohibited from operating in broader regions and since legal actions designed to prevent monopolistic formations are usually focused on smaller banking markets. Yet, what would appear to represent a significant increase in aggregate concentration in some states sometimes does not, in fact, represent any meaningful change in structure. The increases in concentration often involved acquisitions of banks which had formerly operated as members of a banking group unified through common owners and directors and interlocking management. ${ }^{9}$

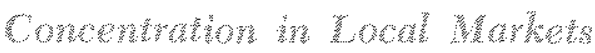

Concentration in local markets is more crucial from a competitive point of view than is concentration nationally or statewide. ${ }^{10}$ In a local market, banks and their customers are in sufficiently close proximity for competitive interaction to occur, and both information and transaction costs tend to rise for many types of services as the distance between the bank and customer increases, reducing the threat of effective outside competition, ${ }^{11}$ Local markets characterized by a structure with relatively few firms and high barriers to entry will facilitate pricing conduct that is aimed at achieving joint profit maximization through collusion, price leadership, or other tacit pricing arrangements. ${ }^{12}$ Nevertheless, greater publicity is given to

\footnotetext{
8Samvel H. Talley, "The Impact of Holding Company
Acquisitions."

"See Nancy M. Goodman, "Holding Company Developments in Michigan," Federal Reserve Bank of Chicago Business Conditions, (October 1975), pp. 10-15.

whis view has been adopted by the U.S. Supreme Court in evaluating competition. See U.S. V. Philadelphia National Bank in 1963; and U.S. v. Marine Bancorporation in 1974.

11 One study concluded that distance dominates all other factors in determining the selection of a banking office. Lorman L. Lundstein and Lewis Manclell, "Consumer Selection of Banking Office - Fiffects of Distance, Services and Interest Rate Differentials," Proceedings of a Conference on Bank Structure and Competition, Federal Reserve Bank of Chicago, ApriI 1977 , pp. $260-286$.

12See Stephen A. Rhoades, "Structure-Performance Studies in Banking: A Summary and Evaluation," Staff Economio Studies (92), Board of Governors of the Federal Reserve System, 1977 .
}

trends in concentration in the nation or at the state level than at the local level. This probably reflects the difficulty of defining a local market, but also reflects a popular misconception that "bigness" alone is a measure of monopoly power.

It appears that concentration has remained unchanged or has decreased in most local banking markets during the period of rapid holding company acquisitions. A study of 213 metropolitan areas and 233 country banking markets over the 1966-75 period concluded that most banking markets became less concentrated in that period. Also, the procompetitive changes in banking market concentration occurred with greatest frequencies and in the largest magnitudes in those markets which had a relatively high concentration ratio in $1966 . .^{13}$ In addition, local areas experiencing $\mathrm{MBHC}$ activity generally had lower initial concentration than areas where no MBHC acquisitions occurred..$^{14}$ Also, MBHCs tend to acquire banks in markets characterized by relatively fast growth in terms of banking offices, and relatively favorable ratios of deposits per banking office. ${ }^{1 \bar{a}}$

One positive influence on local competition may be stringent standards for approval of holding company acquisitions by the Board of Governors of the Federal Reserve System. Before approval is given to a holding company to accuire a bank, the Board analyzes the effects of the proposal on competition in the local banking markets. An application is denied if its effects would be to reduce materially competition in a local market, unless there are other strong mitigating factors. ${ }^{16}$ Managements of relatively large holding companies generally assume that proposed acquisitions of relatively large independent banks in an

${ }^{13}$ Samuel H. Talley, "Recent Trends in Local Banking Market Structure, Staff Economic Studies (89), Board of Governors of the Federal Reserve System, 1977 .

14Jack S. Light, "Bank Holding Companies - Concentration Levels in Three District States," Federal Reserve Bank of Chicago Business Conditions (June 1975), pp. 10-15. See also, Stephen A. Rhoades, "Characteristics of Banking Markets Entered by Foothold Acquisition," Journal of Monetary Economics (July 1976), pp. $399 m 408$, which concluded that the procompetitive effects of holding companies are less than they might otherwise be.

t5Cregory E. Boczar, "Market Characteristics and Multibank Holding Compaty Acquisitions," Joumal of Finanee (March 1977), pp. I31-146.

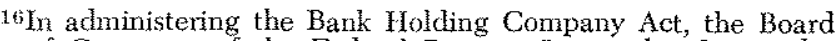
of Governors of the Federal Reserve System has been adamant not only in denying applications by holding companies to acquire existing banks with which they conpete, but in addition, the Board has stood ready to deny applications on the basis of potential competition and probable future competition. See Harvey Rosenblum, "Bank Holding Companies - Part II," Federal Reserve Bank of Chicago Business Conditions (April 1975), pp. 13-15. 
area where the MBHC has a subsidiary would be denied, and few such applications are even submitted.

In analyzing the growth of MBHC subsidiaries after acquisitions, no significant effects in the market share of affliated banks vis-a-vis banks remaining independent were found in four studies. ${ }^{\text {T }}$ This probably reflects offsetting effects of $\mathrm{MBHC}$ affiliation. On the one hand, subsidiaries of MBHCs enjoy greater financial strength and ability to offer a wider range of services. On the other hand, the independent banks, on balance, can probably give more personalized service and adapt more quickly to changing local conditions. Indeed, the independent bank's tesponse to MBHCs in their area has probably intensified competition.

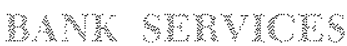

A related issue raised by the $\mathrm{MBHC}$ development is the effect of holding company affiliation on the availability and cost of bank services. The evidence available on bank performance is mostly indirect, such as changes in bank operating ratios; hence, most conclusions are tentative.

It has been argued that holding companies are able to offer more and better banking services to the customers of their affiliates than are independents because of their larger size and superior management. This assertion camot be tested directly, but a reasonable proxy variable for the general quality of banking services is the rate of growth of a bank's deposits. Presumably, banks providing more and better services grow faster than other banks. However, as noted in the previous section, growth of affliates has not been significantly different on average than growth of competing independent institutions.

Federal Reserve System application of the Holding Company Act probably has some influence on fostering better and broadened service by MBHC affiliates. To promote public interest, the Federal Reserve System evaluates the effects of a bank holding company acquisition on the basis of convenience and needs of

\footnotetext{
17Lawrence G. Goldberg, "Bank Holding Company Acquisitions and Their Impact on Market Shares," Journal of Money, Credit and Banking (February 1976), pp. 127-130; Staart Hofman, "The Impact of Holding Company Affiliation on Bank Perfomance: A Case Study of Two Florida Multibank Holding Companies," Working Paper Series, Federal Reserve Bank of Atlanta, January 1976; David D. Whitehead and B. Frank King, "Multibank Holding Companies and Local Mar" ket Concentration," Federal Reserve Bank of Atlanta Monthly Review, (April 1976), pp. 34-43; and Jerome C. Damell and Howard Keen, Jr., "Small Bank Survival: Is the Wolf at the Door?" Federal Reserve Bank of Philadelphia Business Review (November 1974), pp. 16-23.
}

the community to be served. ${ }^{18}$ Every MBHC application to acquire a bank must include a description of changes, if any, the holding company plans to initiate in either availability or prices of services and how these changes will benefit the public. Proposals frequently include establishment of a trust or foreign banking service, raising interest rates on time and savings deposits to Regulation $Q$ maxima, reducing rates on credit insurance premiums, providing data processing services, expanding certain types of loans, and providing more customer facilities, such as park ing lots. Convenience and needs factors alone are seldom the decisive factor in ruling on a case but these pledges can be crucial in determining whether the proposal is approved when it appears that other factors are marginal. ${ }^{19}$ In one study in which stated intentions of MBHC applications were compared with actual implementation, no instances were found in which promised actions were not subsequently taken. In a number of cases, however, intentions were not fully realized..$^{20}$

Even though many MBHCs have implemented promised services and/or reduced prices, the differences between services offered by MBHC banks and other banks have been marginal. Statistical analyses show that bank branching and size are stronger determinants of most bank behavior ratios than $\mathrm{MBHC}$ affiliation. ${ }^{21}$ Affiliated banks tend to reduce cash and low-risk securities and increase loans, suggesting greater credit availability by MBHCs. ${ }^{22}$ Much of the gain, however, reflects the acquisition of a number of formerly ultraconservative banks. The ratio of time and savings deposit interest to total time and savings

18U.S.C., title 12, section 1843, as amended by Acts of July $\mathrm{I}$, 1966 (80 Stat. 238) and December 31, 1970 (84 Stat. 1763).

19 See Michael A. Jessee and Steven A. Seelig, "An Analysis of the Public Benefits Test of the Bank Holding Conpany Act," Federal Reserve Bank of New York Monthly Review (Jure 1974), 15. 157-167.

${ }^{20}$ Joseph E. Rossman and B. Frank King, "Multibank Holding" Companies: Convenience and Needs," Federal Reserve Bank of Atlanta Economic Retiew (July/August 1977), pp. 83-91. This study, however, had basic limitations. For example, the results were based primarily on a survey of MBHCs, taking the company's word for what was done.

"William Jackson, "Nultibank Holding Companies and Bank Behavion," Working Paper 75-1, Federal Reserve Bank of Richmond, July 1975.

"See Lucille S. Mayne, "A Comparative Study of Bank Holding Company Affliates and Independent Banks, 1969-1972," Joumal of Finance (March 1977), pp. 147-158. Another study, however, foumd that within county changes in bank structure in ohio by holding company acquisition did not materially alter the simply of credit. Richard L. Gady, "Performance of Rural Banks and Changes in Bank Structure in Ohio," Federal Reserve Bank of Cleveland Economic Review (November-Decernber 1971), pp. 3-14. 
deposits at MBHC affiliates increased relative to those of independent banks, but the change was not statistically significant. ${ }^{23}$ The ratio of trust revenue to total revenue tends to be higher for affiliates than for independents, from which some analysts conclude that MBHCs offer more trust services. However, empirical evidence indicates that trust revenue of banks in counties in which one or more banks are affliated with holding companies was neither higher nor lower than in other counties, holding other factors constant. ${ }^{24}$

In short, most $\mathrm{MBHC}$ banks resemble non-MBHC banks. ${ }^{25}$ The impact of MBHC management upon the behavior of affiliated banks is best analyzed on an individual bank basis. MBHC acquisition of a "problem bank" or an ultraconservative bank could serve the public interest, whereas an MBHC acquisition of a well-managed independent bank would apparently offer few public benefits.

A study of the effects of 43 acquisitions of rural community banks in Ohio compared with 101 comparable independent banks in the same communities found several interesting impacts of the MBHCs. The affiliates showed a greater preference for consumer lending, but some lack of interest in real estate and farm lending. Affiliate banks charged higher rates of interest on loans, but they required somewhat lower downpayments and extended credit over slightly longer periods. Independent banks generally provided more auxiliary services with special emphasis on farm management consulting and general tax and financial advice. Holding companies introduced a number of services for the acquired banks, such as data processing, marketing, and loan participation arrangements. Some independent banks responded by joining consortia and relying heavily on correspondents in order to obtain comparable services. ${ }^{26}$

The available evidence suggests that MBHC affiliation has produced a slight enlargement in the availability of banking services. Holding companies have

\footnotetext{
23Samuel H. Talley, "The Effect of Holding Company Acquisi" tions on Bank Performance," Staff Economic Studies (69), Board of Governors of the Federal Reserve System, 1972 .

24R. Alton Gilbert, "Trust Revenue of Commercial Banks: The Influence of Bank Holding Comparies," this Review (June 1974), pp. 8-15.

${ }^{25}$ See Robert F. Ware, "Characteristics of Banks Acquired by Multibank Holding Companies in Ohio," Federal Reserve Bank of Cleveland Economic Review (August 1971), pp. $19-27$.

20 Warren F. Lee and Alan K. Reichert, "Effects of Multibank Holding Company Acquisitions of Rural Community Banks," Proceedings of a Conference on Bank Structure and Competition, Federal Reserve Bank of Chicago, May 1-2, 1975, pP. $217-225$.
}

had only a slight net effect on prices of affiliated banks relative to those of the remaining independents. In short, as one might expect in a competitive environment, availability and prices of services have been little different at banks, regardless of corporate form.

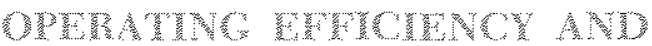

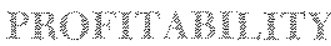

Although it has frequently been contended that one advantage of joining an MBHC is improved operating efficiency for the acquired bank, empirical evidence does not indicate any such clear improve. ment of efficiency of affiliates over independents. The impact of affiliation on operating efficiency and profits is difficult to assess from financial statements since MBHCs may attempt to shift reported profits to the consolidated holding company rather than report them for each affiliate. This may be particularly true where the holding company does not completely own the affiliate. One study found no significant change in operating costs when an MBHC acquired a unit bank and an increase in such costs when it acquired a bank with branches. ${ }^{2 t}$

MBHC affiliates, as components of banking organizations larger than most independent banks, probably experience some economies of scale, ${ }^{28}$ MBHCs are able to consolidate risks by generally having a larger asset base and serving a wider geographical area than most independent banks, reducing cash and capital requirements. Other operating efficiencies for affiliates include better access to capital markets, ${ }^{29}$ advertising, data processing, specialized lending, and trust and foreign banking services.

Although ratios of total revenues to total assets have been higher for affiliates than for independent banks, total operating expenses to total assets have also been higher. ${ }^{30}$ In particular, MBHCs incur larger employee

${ }^{2}$ Donald J. Mullineaux, "Branch Versus Unit Banking: An Aralysis of Relative Costs," Changing Pennsyluanta's Branching Laws: An Economic Analysis, Technical Paper, Federal Reserve Bank of Philadelphia, 1973, pp. 175-227.

:28See Ernst Baltensperger, "Economies of Scale, Firm Size and Concentration in Banking," Journal of Money, Credit and Banking (August 1972), pp. 467-88; and Crnst Baltensperger, "Costs of Banking Activities - Interactions Between Risks and Operating Costs," Journal of Money, Credit and Banking (August 1972), pp. 595-611.

2 Cost of raising capital tends to be lower for large firms than for smaller enterprise. See Roger D. Blair and Yoram Peles, "The Advantage of Size in the Capital Market: Emperical Evidence and Policy Implications," Working Paper 24, Center for the Study of American Business, Washington University, St. Louis, December 1977.

ansee Rodney D. Johwson and David R. Meinster, "The Per" formance of Bank Holding Company Acquisitions: A Multi- 
benefit costs and greater "other expenses" than independent banks. ${ }^{31}$ Because MBHCs are usually the larger banking organizations, one would intuitively expect them to have employee benefit plans which would tend to be extended to subsidiaries. The "other expenses" category includes many diverse bank expenses, and the actual reasons for the higher "other expenses" for holding company banks is not known. One could speculate that costs relating to the holding company structure and included in this category, such as management or legal fees, could conceivably drain some "profits" from the subsidiary banks.

Nevertheless, holding company acquisitions have probably had only moderate effects on prices, expenses, profitability, or performance of acquired banks. $^{32}$ Since MBHCs have slightly higher operating costs than independent banks, it has been contended that affiliation with a holding company entails net diseconomies of scale rather than economies. ${ }^{33}$ Using a different line of reasoning, a study of Alabama banks over the period 1968 to 1973 found that, on balance, technical and operational efficiency improved for both independent and affiliate banks. Since this was a period in which the dominant change in the state's banking industry was the emergence of an aggressive MBHC movement, the findings were tentatively attributed to that activity.34

Since there are significant differences between individual holding companies, it is probably misleading to group them in some average. Many of the performance measures indicate that operations of banks affiliated with particular holding companies differed significantly from both independent banks and banks

variate Analysis," Journal of Business (April 1975), pp. 204-212, and Robett $\mathrm{J}$. Lawence, The Performance of Bank Holding Companies, Board of Governors of the Federal Reserve System, 1967.

"Jack S. Light, "Effects of Holding Company Affitiation on De Novo Banks," Proceedings of a Conference on Bank Structure and Competition, Federal Reserve Bank of Chicago, 1976 , pp. $83^{*} 106$.

32Sanuel H. Talley, "The Effect of Holding Company Acquisition on Bank Performance," Staff Economic Studies (69), Board of Governors of the Federal Reserve System, 1972 . Also, Lucille S. Mayne, "Management Policies of Bank Hold" ing Comparies and Bank Performance," Joumat of Bank Research (Spring 1976), pp. 37-48.

33Dale S. Drum, "MBHCs: Evidence After Two Decades of Regulation," Federal Reserve Bayk of Chicago Business Conditions, (December 1976), pp. 3-15. See also, George J. Benstor and Gerald A. Hanweck, "A Summary Report on Bank Holding Company Affiliation and Economies of Scale," Conferetice on Bank Structure and Competition, Federal Reserve Bank of Chicago (April 1977) pp. 158-168.

34Terrence F. Martell and Donald L. Hooks, "Holding Company Affiliation and Economies of Scale," Journal of the Midwest Finance Assoctation (1975), pp. 59-71. affiliated with other holding companies. It was possible in a number of instances to reject the hypothesis that holding-company-affiliated banks can be treated as elements of a single group as far as performance is concerned, ${ }^{3 \pi}$

Examining the profitability of MBHC banks compared with independent banks through the use of performance ratios has not produced uniform results. In one study, MBHC affiliation was found to have a negative impact on the ratios of net income to total assets and on met income to equity. ${ }^{36}$ Another inquiry found no significant difference in holding company performance on net income to equity from that of independent banks. ${ }^{37}$

Two studies by John Mingo, taken together, hint at a third view of the profitability of MBHC affiliates. The first study found that holding companies tend to purchase banks with earnings to capital ratios below those of other banks. ${ }^{38}$ The second found that holding company banks, after acquisition, tend to have higher net eamings to capital ratios than do independent banks. ${ }^{39}$ A conclusion that MBHCs improved the profitability of acquired banks, however, may not be warranted in view of the changed samples.

The evidence on the profitability of MBHC affiliates is mixed, and the issue is not likely to be settled soon. In a number of cases, subsidiaries have been less profitable than independents of similar size in the same general area. However, the holding company may be attempting to maximize profits of the system rather than for each subsidiary. Also, many acquisitions have been of banks with below average profitability, and it may take more time to get a fair evaluation of their performance within the holding company. To date, only a few MBHC affiliates have been liquidated, sold, or spun off, indicating that any drag on the system's profitability has not been intolerable.

"Arthur G. Fraas, "The Perfomance of Individual Bank Holding Companies," Staff Economic Study (84), Board of Govemors of the Federal Reserve System, 1974.

$36 \mathrm{Jack}$ S. Light, "Effects of Holding Company Affiliation on De Nowo Banks," Proceedings of a Conference on Batk Structure and Competition, Federal Reserve Bank of Chicago, May 1976, pp. 83-106.

37Williarn Jackson, "Multibank Holding Comparies and Bank Behavior," Working Paper 75-1, Federal Reserve Bank of Richmond, July 1975.

38john J. Mingo, "Capital Management and Profitability of Prospective Holding Company Banks," Joumal of Financial and Quantitatice Analysis (June 1975), pp. 191-203.

${ }^{39}$ John J. Mingo, "Managerial Motives, Market Structure and the Perfomance of Holding Company Banks, Economic Inquiry (September 1976), pp. 411-424 


\section{WANK SONOWES}

Holding companies claim that they strengthen acquired banks in a number of ways. At times, they provide additional capital, personnel training, or skilled management. They diversify risks and lower the costs of providing certain specialized services. Resources of the entire system can be mobilized to solve a local bank's problems. Yet, most analyses have indicated that the alleged benefits of MBHCs on bank soundness are exaggerated. It is still not clear whether the holding company movement has, on balance, increased or reduced the soundness of banks.

The Board of Governors of the Federal Reserve System denies applications of proposed holding company acquisitions if the payments necessary to retire debt incurred in buying the bank's stock would be likely to drain its retained earnings. In addition, capital has been supplied by the parent holding companies to a number of subsidiaries. Nevertheless, the capital positions of a number of acquired banks have been relatively low. The average ratio of capital to total assets or deposits is generally lower for affiliated banks than for independent counterparts. ${ }^{40}$ However, it has been found that holding company affiliation caused only a small decline in the capital to deposits ratio, one which was not statistically significant. ${ }^{41}$

MBHC banks, on average, are leveraged to a greater extent than independent banks (as measured by lower capital/asset ratios), and hold greater proportions of higher-yielding (presumably more risky) assets than do comparable independents. Also, as market concentration increases, capital to asset ratios rise for inde. pendent banks as a class but decline for holding company banks. Such observations suggest that independent banks take most benefits of greater market power in the form of reduced risk, while MBHC banks are less risk-averse. Although affiliation tends to increase the payout ratio (dividends to net income) for affiliated banks, ${ }^{40}$ the funds may still be retained within the MBHC organization.

\footnotetext{
"0See Arthur G. Fraas, "The Performance of Individual Bark Holding Companies," Staff Economic Study (84), Board of Governors of the Federal Reserve System, 1974, and William Jackson, "Multibank Holding Companies and Bank Behayior," Working Paper 75-1, lederal Reserve Bank of Richmond, July 1975 .

41Talley, "The Effect of Holding Company Acquisitions on Bank Performance."

42John J. Mingo, "Managerial Motives, Market Structures, and the Perfomance of Holding Company Barks."

43Jackson, "Multibank Holding Companies and Bank Behavior."
}

Through the use of the holding company, some organizations have engaged in "double leveraging" that is, raising funds through parent debt issues and "downstreaming" equity capital to bank subsidiaries. This practice allows the subsidiaries to increase reported capital ratios, while increasing the leverage of the holding company as a whole. ${ }^{44}$

A conclusion that affiliated companies hold less capital to assets or deposits than their independent counterparts does not necessarily indicate that they are undercapitalized or less stable. ${ }^{45}$ The risks of banking are ustually more diversified by having a larger asset base, by engaging in more activities and by operating over a wider region in an MBHC arrangement than for an individual bank. Since such diversification reduces the lead bank's risk, the MBHC might assume a somewhat greater risk in each of its subsidiaries than otherwise without increasing the exposure of the system. ${ }^{40}$ Hence, even though an individual affiliate has less capital cushion, this might be matched by help it could reasonably expect from its parent should aversity arise. ${ }^{47}$

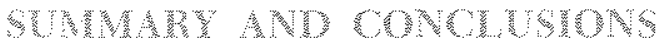

Despite a tremendous expansion of MBHCs during the last decade, commercial banking has changed only moderately as a result of these activities. ${ }^{48}$ Recognizing that it is too early to appraise adequately all the ramifications, the weight of the evidence so far seems to indicate that the net effects of the holding company

${ }^{4} \div$ See Federal Reserve Bulletin (February 1976), p. 115 .

4nsee "Bank Holding Company Financial Developments in 1976," Federal Reserve Bulletin, Board of Covernors of the Federal Reserve System (April 1977), pp. 337-340.

toLeverage was found to be statistically significant in explaining market risk premium on long-term debt when bank issues alone were examined, but was statistically insignificant when issues of bank holding companies alone were analyzed. Anne $S$. Weaver and Chayim Merzig-Marx, "A Comparative Study of the Effect of Leverage on Risk Premiums for Debt Issues of Banks and Bank Holding Companies," Staff Memoranda, Federal Reserve Bank of Chicago, 1978.

47 Nevertheless, the potential benefits from diversification in MBHC organizations has been found to be limited due to the relatively homogeneous nature of holding company acquisitions of banks. See Peter S. Rose, "The Pattem of Bank Holding Company Acquisitions," Journal of Bank Research (Autumn 1976), pp, 236-240.

48See Stephen A. Thoades, "Structure and Performance Studies in Banking: A Summary and Evaluation," Staff Economic Studies (92), Board of Governors of the Federal Reserve System, December 1977 , D. 45 . Based on a review of 39 studies of market structure and perfornance published since 1959 it was concluded that the changed makket structure has had only a small quantitative effect on price or profit performance in banking. 
movement have been favorable for the general public. The fear that commercial banking would become less competitive if holding companies were permitted has not been substantiated. In many local markets, affiliates of MBHCs have increased competition, and the independent bank's response to the introduction of a holding company competitor has frequently also been to intensify competition.

On balance, MBHCs have offered a slightly wider range of banking services and have increased credit extended to consumers and small businesses over what otherwise would have been likely. As a result, revenues of affiliates have been higher than at independent banks, but costs have also been greater.

Affiliates of MBHCs are not as well capitalized as their independent counterparts, but risk is reduced through greater diversification. Independent banks do not seem to have been harmed by the introduction of a holding company operation in their market area, having grown at roughly the same rate as similar-sized MBHC affiliates. Evidence on profitability of affiliates versus independent banks is still mixed.

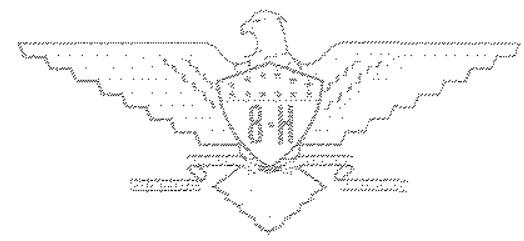

